DOI: https://doi.org/10.18371/fp.2(38).2020.209284

УДК 336.647 .2

\title{
ПРІОРИТЕТНІ НАПРЯМИ РОЗВИТКУ ФІНАНСОВОГО ЗАБЕЗПЕЧЕННЯ СІЛЬСЬКОГОСПОДАРСЬКИХ ПИПРИЕМСТВ
}

\author{
КОВАЛЬОВА Аліна Олександрівна \\ acnip анm \\ Херсонський державний аграрно-економічний університет \\ ORCID ID: https://orcid.org/0000-0002-2086-7168 \\ e-mail: Alinakovaleva271988@gmail.com
}

Анотація. Фінансові ресурси є основою для успішного ведення підприємницької діяльності та розвитку галузі в иілому. У статті досліджено основні форми фінансування сільськогосподарських підприємств та розроблено алгоритм покращення прочесу їх залучення. Розроблено пріоритетні напрями розвитку фінансового забезпечення сільськогосподарських підприємств з використанням поєднання різних форм фінансування.

Ключові слова: фінансові ресурси, фінансове забезпечення, форми фінансування, сільське господарство, підприємство.

Постановка проблеми. Галузь сільського господарства є однією з найперспективніших i найризикованіших для ведення підприємницької діяльності. Для ефективного функціонування підприємств галузі необхідним є наявність у достатньому обсязі фінансових ресурсів. Тому значну увагу приділяють пошуку та залученню нових джерел фінансування для успішного розвитку підприємств й утримання конкурентоспроможності на достатньому рівні. Проблема дефіциту коштів, важкої доступності до усіх видів ресурсів постає перед більшістю підприємств. Адже пи-
Аннотация. Финансовые ресурсы есть основой для успешного ведения предпринимательской деятельности и развития отрасли в целом. В статье исследованы основныле формы финансирования сельскохозяйственных предприятий и разработан алгоритм улучшения процесса их привлечения. Разработань приоритетные направления развития финансового обеспечения сельскохозяйственных предприятий с использованием сочетания различных форм финансирования.

Ключевые слова: финансовые ресурсы, финансовое обеспечение, формы финансирования, сельское хозяйство, предприятие.

тання забезпеченості фінансовими ресурсами гостро постає на сільськогосподарських підприємствах, особливо в період сезонного виробничого процесу. Саме тому дієвий пошук джерел фінансування та раціональне використання фінансових ресурсів є актуальною проблемою, яка потребує пошуку шляхів вирішення.

Аналіз останніх досліджень і публікацій. Тема фінансування сільськогосподарських підприємств та виявлення основних переваг та недоліків можливих форм фінансового забезпечення $\epsilon$ актуальною серед науковців. Цьому пи- 
танню приділяють увагу такі вчені, як В.П. Галушко, О.С. Гудзь, С.О. Гуткевич, М.С. Герасимчук, М.I Кісіль, А.А. Пересада, Г.М. Підлісецький, В.П. Савчук, П.А. Стецюк, Н.С. Танклевська, А.М. Третяк, А.В. Чупіс. Оспіщева В.I. та Пилипенко I.I. зазначають, що «фінансове забезпечення - це поняття потреб фінансового відтворювального процесу за рахунок власних або залучених коштів» [1, с.81]. Філіна Г.І. стверджує, що основним завданням фінансування $\epsilon$ мобілізація коштів для здійснення операційної та інвестиційної діяльності [2, с.13]. Питанню фінансового забезпечення та формам їх залучення належить велика кількість наукових праць. Оспіщева В.І., Кириленко О.П., Буряк П.Ю., Смолінська С.Д., Татарин П.Б., Александрова М.М. виділяють п'ять форм фінансового забезпечення: бюджетне фінансування; кредитування; самофінансування; оренда (лізинг); інвестування [3, с.22; 4, с. $212 ; 5$, с.392; 6, с.36]. Проблемі ефективного залучення фінансових ресурсів для функціонування сільськогосподарських підприємств приділяють дуже багато уваги. Проте аналіз останніх публікацій показав, що на даний момент стан підприємств даної галузі у своїй більшості $є$ незадовільним, а питання пошуку та використання фінансових ресурсів залишаються актуальними і потребують подальших досліджень.

Метою дослідження $\epsilon$ розробка пріоритетних напрямів розвитку фінансового забезпечення сільськогосподарських підприємств, пошук нових та поєднання уже існуючих форм фінансування.
Виклад основного матеріалу. Однією із найважливіших галузей економіки є галузь сільського господарства. Системні перетворення аграрної сфери зумовлюють сільськогосподарські підприємства до адаптації та вимагають пристосованості їх до ринкових умов. Для проведення підприємницької діяльності перед підприємствами гостро постає питання ресурсного забезпечення, передусім фінансового. Саме вирішення даних проблем є стратегічно важливими і необхідними не лише для суб' єктів підприємницької діяльності, а й для фінансової системи в цілому. Аграрний сектор відіграє визначальну роль у формуванні та функціонуванні фінансового потенціалу економіки країни.

Для успішного ведення підприємницької діяльності характерним є стабільність та ефективність налагодженого дієвого механізму залучення фінансових ресурсів. Фінансові ресурси забезпечують функціонування підприємства за усіма напрямками його діяльності, а саме: безперервність процесу відтворення через фінансування поточних витрат; виконання зобов'язань перед державою, працівниками та контрагентами; страхування капіталу від фінансових ризиків; стабільний розвиток та ділову репутацію підприємства; соціальне забезпечення працівників.

Сільське господарство має ряд особливостей, які впливають на рівень ризику, а саме: сезонність, значна тривалість виробничого циклу, потреба в кредитних ресурсах, використання оренди землі. Фінансові ресурси мають здатність до трансформації і у більшості випадків активізуються у період се- 
зонної потреби у вигляді виробничих та залучених ресурсах або страхуванні від фінансових ризиків. Також, слід відзначити, що рівень ризику для сільськогосподарських підприємств підвищується в залежності від грунтово-кліматичних умов, де здійснюється процес виробництва. Природна сезонність та якість грунтів мають суттєві організаційноекономічні наслідки, які знаходять своє відображення у нерівномірному використанні робочої сили та засобів виробництва, у значній тривалість виробничого циклу та періоді окупності матер іальних та фінансових ресурсів, що потребують підвищену потребу у залученні фінансового капіталу для здійснення господарської діяльності на якісному технічному та технологічному рівні. Саме тому, для покращення стану підприємства та активізації його діяльності нами запропоновано алгоритм покращення процесу залучення фінансових ресурсів сільськогосподарських підприємств (рис.1).

Проте, одна з головних відмінностей сільського господарства від інших галузей економіки $є$ використання земельних ділянок, які протягом тривалого періоду залишаються у обороті. Оскільки земля, як основний засіб виробництва, вимагає відтворення на розширеній основі, це в свою чергу зобов'язує товаровиробників вкладати основні та обігові кошти, а також залучати інвестиції з розрахунку об'єму землекористування. Також суб'єкт господарської діяльності незалежно від суми отримання прибутку чи збитку повинен сплатити орендну плату за користуван- ня земельними ділянками. У своїх працях Гудзь О.Є. визначає, що збільшення обсягів орендних виплат мало залежить від збільшення виробництва валової продукції і зовсім немає зв'язку з обсягами прибутків [7, с. 15].

Важливою складовою процесу залучення фінансових ресурсів $є$ постановка мети та визначення цілей підприємства, які є відображенням загальної стратегії фінансування підприємства. Основним завданням при формуванні мети підприємства $\epsilon$ виявлення потреби у фінансових ресурсах, яка визначається відповідно до виду діяльності господарюючого суб' єкта, а саме господарської, виробничої, маркетингової, зовнішньоекономічної, фінансової діяльності тощо.

Беручи до уваги потребу у фінансових ресурсах, наступним кроком $є$ пошук джерел фінансового забезпечення, а саме власні, залучені та позичені грошові чи матеріальні надходження. Власні фінансові надходження формуються внаслідок чистого доходу від діяльності, фінансової допомоги на безоплатній основі. Позичені фінансові ресурси підприємство отримує у вигляді позик та кредитів від фінансово-кредитних установ. Даний вид ресурсу має цільовий характер, термін використання та обов' язкову сплату кредитору відсотків за його використання. Ці кошти обтяжують позичальника величиною плати за кредит, але якщо рівень прибутковість зростає, то використання даного виду ресурсів є доцільним та обгрунтованим. 


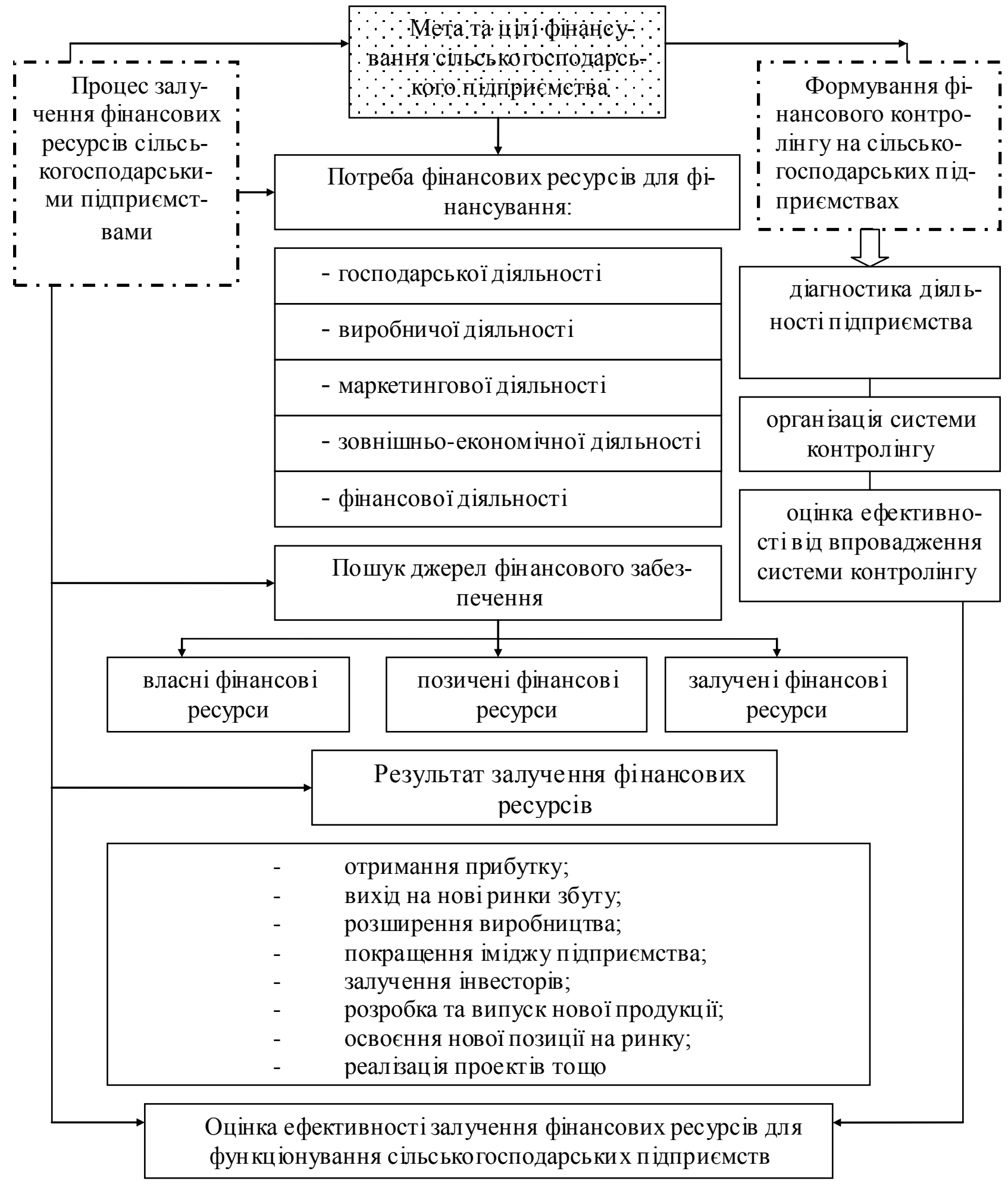

Рис. 1 Алгоритм покращення процесу залучення фінансових ресурсів сільськогосподарських підприємств

Джерело: побудовано автором

Залучені кошти є певною відстрочкою від обов'язкових платежів підпри- ємства перед засновниками, партнерами та бюджетом. Такі кошти, зазвичай, не 
обтяжують підприємство додатковою платою за їх використання, проте, надмірне застосування цього джерела погіршує ділову репутацію підприємства. Отже, забезпечення фінансування власними коштами $€$ найбільш вигідним та часто недостатнім для задоволення усіх потреб підприємства. У такому випадку необхідним $є$ використання та поєднання залучених, позикових коштів, що як наслідок покращує показники ефективності підприємства.

Відповідно від залучення потрібного обсягу фінансових ресурсів, слід окреслити результат, який плануємо отримати, а саме збільшення прибутку (зменшення збитку); вихід на нові ринки збуту; розширення об'ємів виробництва; покращення іміджу підприємства; створення сприятливих умов для залучення інвесторів; розробка та випуск нової продукції; освоєння нової позиції на ринку; збереження конкурентоспроможності; реалізація проектів різних напрямів тощо.

Завдання по формуванню та використанню фінансових ресурсів сільськогосподарського підприємства вирішують виключно керівництвом та спеціалістами фінансово-економічного чи бухгалтерського відділу. При цьому відсутність належного взаємозв'язку між підрозділами підприємства можуть поставити під загрозу розвиток підприємства. Саме тому при формуванні процесу залучення фінансових ресурсів нами запропоновано застосовування системи фінансового контролінгу. Саме за допомогою фінансового контролінгу вирішення знаходять такі питання, як розробка та реалізація стратегії фінансового забезпечення, здійснення координа- ції підсистем управління, внутрішнього контролю, консалтингу, управління ризику та забезпечення інформаційної підтримки керівництва, що $є$ особливо важливим для збиткових підприємств.

Формування фінансового контролінгу поділено на три етапи. Перший етап - підготовчий, здійснюється діагностика фінансово-господарської діяльності підприємства та приймається рішення про готовність впровадження контролінгу на підприємстві. На другому етапі впровадження, розробка бюджету впровадження контролінгу, обгрунтування методик та інструментів фінансового контролінгу відповідно до специфіки діяльності господарства та створення комплексної системи інформаційного забезпечення. На третьому - підсумковому етапі формують комплекс дій щодо оцінки ефективності від впровадження фінансового контролінгу, аналіз відхилень та розробка коригуючи заходів.

Останньою складовою алгоритму покращення процесу залучення фінансових ресурсів сільськогосподарських підприємств є оцінка його ефективності, під час проведення якої нами згруповано фінансово-економічні показники відповідно до їх належності. До таких груп показників належать: стійкості підприємства, ділової активності, ліквідності і платоспроможності, рентабельності, показники визначення рівня банкрутства та рівня динаміки розвитку. Саме застосування інтегрального показника фінансово-економічного стану підприємства є узагальнюючим показником, що характеризує фінансовогосподарську діяльність господарюючого суб'єкта. 
Нами запропоновано організаційноекономічний механізм впливу на формування фінансових ресурсів сільськогосподарських підприємств, за допомогою якого можна ефективно оптимізувати управління фінансовими ресурсами та в подальшому розширити потенційні фінансові можливості підприємства. Суть даного механізму полягає у організації процесу формування та використання фінансових ресурсів сільськогосподарського підприємства під впливом зовнішніх та внутрішніх важелів. Зовнішні важелі впливу діють завдяки координації аграрної, фіскальної, бюджетної, цінової, страхової, банківської, інвестиційної політик країни, які визначають стан політико-економічної системи, міжнародних інтеграційних перетворень аграрного сектора. Також створюють конкурентоспроможність на ринку; здійснюють розробку та реалізацію основних напрямів реформування економічних, соціальних та правових відносин у сфері агропромислового виробництва, структурної перебудови галузей агропромислового виробництва; оптимізацію та раціоналізацію використання державних фінансових ресурсів; забезпечення збалансованості на ринку засобів виробництва, товарів і послуг. До внутрішніх важелів впливу належать фінансова, кадрова, соціальна, матеріально-технічна, амортизаційна політика та структура управління підприємством. Дані складові тісно взаємопов' язані між собою та при злагодженій роботі дають позитивний результат діяльності підприємства.

Для регулювання підприємницької діяльності важливого значення набуває нормативно-правове забезпечення, яке діє відповідно до Конституції України, указів Президента України, законів та постанов Верховної ради України, нормативно-правових актів міністерств. При формуванні фінансових ресурсів необхідним $\epsilon$ консультаційноінформаційне забезпечення сільськогосподарських підприємств. Головною метою процесу даного забезпечення $\epsilon$ створення мережі консультаційноінформаційне установ, які охоплюють своєю діяльністю підприємства аграрного сектора. Слід відзначити, що служби розповсюдження сільськогосподарських знань та інформації (дорадництва) $є$ важливим інструментом держави у розповсюдженні досягнень у розробці нової техніки та технології виробництва. проте підприємства сільського господарства $\epsilon$ обмеженими у об'єктивній, своєчасній та повноцінній інформації. Загалом, питання надання послуг, формування та функціонування аграрного ринку, розвитку інфраструктури села все більше набувають особливої ваги, адже від темпів їх вирішення залежить подальший розвиток агроформувань. В даному напрямку робота зводиться до надання консультаційних послуг.

Отже, необхідним є створення повноцінної інформаційної системи в напрямах облікового процесу та системи обліку. Саме тому, поширення набувають послуги аутсорсингу, які полягають у передачі підприємством завдань стороннім виконавцям на умовах субпідряду. Завдяки аутсорсингу підприємство може зосередитися на виготовленні чи створення своєї продукції. Перевагою підприємства, яке надає даний вид послуг, $\epsilon$ кваліфікація працівників та 
професійні якості, що є запорукою здійснення своєчасних та нормативно обгрунтованих операцій.

До основних позитивних факторів використання аутсорсингу є зменшення кількості персоналу, а у зв'язку з цим і зменшення витрат на оплату праці; зменшення ризиків пов'язаних із фіскальними та трудовими спорами; підвищення якості ведення звітності. Також характерним для аутсорсингових підприємств є безпека конфеденційних та інформаційних даних підприємств, взятих на обслуговування. Аутсорсингові підприємства використовують методи шифрування, проводять навчання персоналу $з$ приводу запобігання шахрайства. За період 2017-2018 рр. в Україні кількість компаній збільшилась на 128

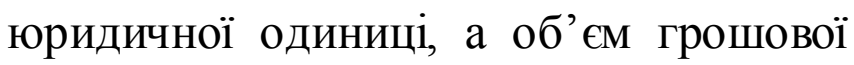
винагороди збільшився у 2018 році на 21,3\%, порівнюючи 2017 роком і становив 2,4 млрд.грн. Найбільша частка аутсорсингових компаній знаходиться у м. Київ та області - 60,14\%, м. Харків $6,29 \%$, м. Львів- 4,20\%, м. Житомир $3,50 \%$, м. Дніпро - 3,50\% та ін.

Окремо хочемо виділити зв'язок структури управління на формування фінансових ресурсів сільськогосподарського підприємства. Так як організаційно-правова форма господарювання суттєво впливає на вибір форми та джерела фінансового забезпечення. Згідно ст. 63 Господарського кодексу України та особливостей реформування аграрного сектора, сільськогосподарські підприємства представлені декількома групами сільськогосподарських формувань: господарські товариства (акціонерні товариства та товариства 3 обмеженою відповідальністю), приватні підп- риємства, фермерські господарства, сільськогосподарські виробничі кооперативи, державні підприємства та інші формування [8, с. 31].

До господарських товариств належать акціонерні товариства, товариства 3 обмеженою відповідальністю, товариства 3 додатковою відповідальністю, повні та командитні товариства. Дані підприємства створені фізичними чи юридичними особами шляхом об'єднання майна та підприємницької діяльності з метою отримання прибутку. Перевагою господарських товариств $\epsilon$ формування статутного капіталу за рахунок внесків власників відповідно до їх части у вигляді матеріальних і нематеріальних цінностей. Це забезпечує певний обсяг фінансових ресурсів для проведення підприємницької діяльності та розширення виробництва.

Сільськогосподарське акціонерне товариство може бути створене однією або кількома фізичними чи юридичними особами, які здійснюють державну реєстрацію товариства і організовують емісію акцій даного підприємства. Такі підприємства створюють у вигляді публічних акціонерних товариств або приватних акціонерних товариств, що визначає масштаби поширення емітованих акцій на ринку. Так, акціонерні товариства використовують емісію акцій як один із способів поповнення власного капіталу грошовими коштами. При успішному веденні підприємницької діяльності даним підприємствам випадає можливість здійснити додаткову емісію акцій або збільшити номінальну вартість уже випущених, що в подальшому дасть можливість збільшити роз- 
мір статутного капіталу та залучити додаткові власні фінансові ресурси.

Найбільш поширеною організаційноправовою формою $є$ товариство з обмеженою відповідальністю, які формують фінансові ресурси з внесків учасників. У процесі господарювання дані підприємства збільшують розмір власного капіталу шляхом додаткових внесків засновників та тезаврації прибутку, а позичений капітал складається 3 кредитів взятих на суму відповідно до розміру власного капіталу.

Проте, такі вчені як, Терещенко О.О., Недільська Л.В., Дорохова Л.М., Дем'янюк І.В. вчені зазначають, що малосприятлива економічна ситуація та недостатня наукова розробка питань залучення фінансових ресурсів не ефективно впливає на формування фінансових ресурсів сільськогосподарських підприємств. На селі набувають поширення створення і функціонування акціонерні товариства, які не мають акцій, дивідендів та інвестицій. Початкові фінансові ресурси є лише успадкованими та мають форму малопридатного майна [8, c. $17 ; 9$, с. $75 ; 10$, с. 112$]$.

Найбільшого поширення серед сільськогосподарських формувань набули приватні підприємства, створені одним чи кількома громадянами без обмеження розміру статутного фонду, а майнові та земельні відносини основані на оренді земельних паїв. Особливістю даного типу підприємств $\epsilon$ можливість реінвестувати прибуток в повному обсязі, а залучати кредитні ресурси лише в обсязі, який не перебільшує половини власного майна позичальника.

Фермерські господарства характеризуються обмеженістю фінансових ресу- рсів, що негативно впливає на купівельну спроможність якісного насіннєвого матеріалу, техніки. Проте даний вид підприємств використовуе зовнішне фінансування у вигляді державної підтримки на виробництво продукції рослинництва та тваринництва, фінансова підтримка через механізм здешевлення кредитів тощо.

Характерною ознакою виробничих кооперативів $\epsilon$ прибуток, який в першу чергу, призначений для розподілу між підприємствами-членами кооперативу, а не для поповнення власних фінансових ресурсів. Лише частина прибутку залишається в розпорядженні кооперативу з метою капіталізації.

Найменш поширенішою організаційно-правовою формою функціонування сільськогосподарських підприємств $\epsilon$ державні підприємства, фінансування яких відбувається за рахунок державного бюджету та цільових грошових фондів міністерств. Фінансова діяльність даних підприємств проводиться за допомогою позичених та залучених ресурсів.

Формування дієвої системи забезпечення фінансовими ресурсами сільськогосподарських підприємств є багатовекторною проблемою 3 урахуванням специфіки виробництва. Розглядаючи галузеві особливості діяльності аграрних підприємств, варто відзначити. що серед них є суб'єктивні - фактичний стан діяльності підприємства в сучасних умовах та об' єктивні, до яких належать особливості сільськогосподарського виробництва. Вважаємо доцільним розробити систему фінансового забезпечення сільськогосподарських підприємств. Суб'єктами даної системи 
виступають фінансові банківські установи, держава та державні органи та сільськогосподарські підприємства, а об’ єктом є складові системи фінансового забезпечення.

Основною передумовою ефективного залучення фінансових ресурсів є злагоджена робота іiі суб' єктів. У нами запропонованій системі, держава та державні установи (служби) повинні взяти на себе роль координатора злагодженої роботи економічної системи країни та виступати головними стимуляторами процесу залучення фінансових ресурсів сільськогосподарськими підприємства через проведення зваженої аграрної політики; активізацію та розвитку фондового ринку; законодавчого забезпечення; покращення інвестиційної привабливості та спрямування інвестиційних ресурсів на розвиток інфраструктури сільських територій; формування ефективних принципів розподілу бюджетних коштів 3 контролем їх використання; запровадження дієвого механізму співпраці сільськогосподарських товаровиробників та державних організацій тощо.

Фінансові банківські установи завдяки співвідношенню потреб сільськогосподарських підприємств та можливостей економічної системи можуть розширити доступність до джерел фінансових ресурсів. Доступ аграріїв до кредитних ресурсів надає можливість сільськогосподарським підприємствам розширити обсяги виробництва та збільшити обсяг обігових коштів. Взаємовідносини підприємств та фінансових банківських установ $є$ взаємовигідними: зростання обсягів кредитних вкладень для комерційних установ збільшує до- хідність активних операцій у вигляді сплати відсотків за користування кредитами, а для підприємств - ефективне використання кредитних коштів дає можливість покривати витрати з метою безперервності виробничого процесу.

Форми фінансового забезпечення сільськогосподарських підприємств поділяються на самофінансування; кредит; бюджетне фінансування; додаткове фінансування та інвестування. Така класифікація враховує специфіку виробничої діяльності аграрних підприємств і дає змогу змістовніше проводити дослідження форм забезпечення підприємств фінансовими ресурсами. Різні форми фінансування можуть застосовуватися одночасно. Хоча найчастішим $\epsilon$ поєднання самофінансування та кредиту. Важливого значення має знаходження та встановлення між різними формами оптимального співвідношення.

Власний капітал формується за рахунок внесків власників підприємства або шляхом реінвестування прибутку. Хоча, деякі літературні джерела стверджують, що процес самофінансування відбувається за допомогою нерозподіленого прибутку, амортизаційних відрахувань та доходів майбутніх періодів.

Кредит як форма руху позичкового капіталу виконує функції акумуляції та вкладення тимчасово вільних грошових коштів. Банківське кредитування сільськогосподарських підприємств здійснюється державними та комерційними банками, які провадять свою діяльність відповідно до закону України «Про банки та банківську діяльність» [11]. Також надання кредитних ресурсів здійснюється позабанківськими установами, 
до яких належать: лізингові, іпотечні, факторингові компаніі, кредитні спілки. В залежності від кредитора кредит класифікують на комерційний, який надають постачальники засобів виробництва, та кооперативний (надається кредитними спілками та кооперативами). Сучасні умови банківського кредитування не вирішують проблеми залучення фінансових ресурсів для покриття сезонних витрат. Сільськогосподарські підприємства не відповідають вимогам оцінки кредитоспроможності позичальника, що проводиться комерційними кредитами, так як більшість підприємств нерентабельні і не мають достатнього забезпечення. При комерційному кредиті, на відмінну від банківського, використовується товарна форма кредиту, а боргові зобов'язання оформляються у вигляді векселя.

Бюджетне фінансування $\epsilon$ одним is заходів державної підтримки функціонування сільськогосподарських підприємств, яке здійснюється за рахунок асигнувань, субсидій і дотацій $з$ державного, місцевих бюджетів та різних фондів цільового призначення 3 метою здійснення регулювання та підтримки діяльності товаровиробників. Бюджетні трансферти повинні мати цільовий та регулярний характер і спрямовувати фінансування державних програм розвитку аграрної галузі.

Додаткове фінансове страхування об’ єднує в собі безповоротну фінансову допомогу, спонсорську допомогу та страхування. Аграрне страхування $\epsilon$ одним 3 найскладніших та важкопрогнозованих ризиковим видом страхування, оскільки страхуються біологічні об’єкти, що знаходяться у процесі роз- витку. Тобто страхуються рослини, які мають забезпечити певний обсяг урожаю, який повинен завчасно бути сплановано та вирахувано фахівцем згідно договору страхування.

Діяльність по залучення інвестицій можна виокремити в окрему форму фінансового забезпечення. Залучення інвестиційних фінансових ресурсів вимагає систематизації діяльності підприємства, створення власного бренду чи торговельної марки. Відзначимо, що в Україні $\epsilon$ правове забезпечення інвестиційної діяльності, за якого інвесторам гарантується захищеність їхніх коштів, стабільні та своєчасні виплати за інвестиційними вкладами. Проте несприятливі внутрішні фактори мають негативний вплив: рівень компетентності та послідовність дій органів влади, відповідність норм законодавства та рівень його дотримання, високий рівень корупції.

До фінансових інструментів нами віднесено податкові платежі, ціноутворення, кредитні інструменти та інструменти боргу, фондові та валютні інструменти. Фінансові інструменти системи фінансового забезпечення сільськогосподарських підприємств певною мірою мають вираження через права на ресурси (активи), які повинні відповідати вимогам: вільний обіг (здатність купуватися та продаватися на ринку, виступати як самостійний платіжний інструмент); документальність (повинні містити передбачені законодавством реквізити), регулювання i визнання державою; ліквідність (здатність бути швидко реалізованими); ризикованість (можливість втрат). Отже, фінансовими інструменти формування і використан- 
ня фінансових ресурсів посилюється вплив на підвищення результативності господарської діяльності через важелі впливу.

До фінансових важелів впливу на формування фінансових ресурсів слід віднести норми і нормативи; умови і порядок формування доходів; порядок здійснення витрат. поняття «норма» $\mathrm{i}$ «норматив» $є$ умовними і їх сутність можна виокремити даючи характеристику: норма - це абсолютні величини витратна одиницю продукції фінансових ресурсів, а нормативи дають оцінку режиму їх використання. Затверджені норми, нормативи є обов'язковими при організації підприємницької діяльності та основою нормативної бази підприємства. До системи нормативної бази сільськогосподарських підприємств відносять нормативи оборотних засобів на потреби виробництва, норм запасів та резервів, нормативи розподілу прибутку, нормативи залишків готівки, нормативи залучення кредитів тощо.

Порядок формування доходів і здійснення витрат $\epsilon$ основою для ведення бухгалтерського та податкового обліку суб' єкта підприємницької діяльності. Фінансові важелі впливають на прийняття управлінського рішення при плануванні необхідного обсягу фінансових ресурсів сільськогосподарського підприємства. Фінансові важелі впливу реалізуються через стимули та санкціі. До стимулів відносять заохочення такі, як дохід, дивіденди, податкові пільги та бюджетне фінансування. До санкцій належать штрафи, пеня та обмеження. Кожний із цих фінансових важелів має функціональну ознаку та характерні засоби впливу. Але всі вони взаємозумов- лені, взаємопов'язані і становлять єдину комплексну систему, яка використовується при формуванні фінансового забезпечення сільськогосподарських підприємств.

Систематизація вищенаведеного дозволяє визначити основні пріоритетні напрями розвитку фінансового забезпечення (рис.2.), зокрема: використання алгоритму покращення процесу залучення фінансових ресурсів сільськогосподарських підприємств; збільшення власних фінансових надходжень шляхом збільшення прибутку підприємства; нарощення економічної ефективності виробництва, оптимізація витрат; пошук нових можливих зовнішніх джерел фінансування через залучення нових інвесторів використання нових нетрадиційних форм фінансування; балансування фінансових потоків за рахунок прискорення оборотності капіталу; удосконалення системи розрахунків і платежів через здійснення факторингових операцій; надання цінових знижок за умови швидкого розрахунку за реалізовану продукцію; використання примусового стягнення боргу та застосування штрафних санкцій; акумуляція коштів за рахунок створення запасів та їх моніторинг; удосконалення облікової роботи, застосування різних видів зовнішнього та внутрішнього контролю; оптимізація використання фінансових ресурсів за рахунок комплексного використання сировини, спрямоване на збільшення асортименту та обсягів виробництва продукції; спрощення механізму надання кредитів для підприємств малого та середнього бізнесу та введення диференційованих ставок по кредиту; розвиток аграрного страхування. 


(n)

Рис.2. Пріоритетні напрями розвитку фінансового забезпечення фінансов ими ресурсами сільськогосподарських підприємств

Джерело: авторська розробка

Висновки. Отримання прибутку $\epsilon$ основним стимулом розвитку підприємства, тому актуальним є урегулювання виваженої державної політики щодо діяльності підприємств, а саме розширення можливостей доступу суб'єктів підприємницької діяльності до фінансових, трудових та інших ресурсів; розвиток інфраструктури підтримки аграрного бізнесу; усунення недосконалостей законодавчої бази в тому числі перегляд системи оподаткування; усунення організаційних перешкод підприємницької діяльності.

Отже, процес залучення фінансових ресурсів $\epsilon$ основною складовою, що дає можливість підприємству функціонувати та досягати поставлені перед ним цілі. Фінансові ресурси для створення підприємства чи ведення господарської 
діяльності залучаються у формі: грошових коштів, матеріальних цінностей (будівлі, машини, транспортні засоби), матеріальні оборотні активи (запаси сировини, хімікатів, добрив тощо), нематеріальних активів (патентні права, ноухау тощо), біологічні активи (худоба, багаторічні насадження), фінансові активи (цінні папери), земельні ділянки.
Від рівня фінансового забезпечення залежить ефективність функціонування не тільки окремого підприємства, а й галузі в цілому. Застосування визначеного комплексу пріоритетних напрямів у певній послідовності сприятиме розвитку фінансового забезпечення сільськогосподарським підприємств.

\section{Список використаних джерел}

1. Кремень О.І. Фінанси. Київ : Центр учбової літератури, 2012. 81 с.

2. Філіна Г.І. Фінансова діяльність суб’ єктів господарювання. Київ : Центр учбової літератури, 2009. 13 с.

3. Оспіщева В.І. Фінанси: курс для фінансистів. Київ : Знання, 2008. 22 с.

4. Кириленко О.П. Фінанси (теорія та вітчизняна практика). Тернопіль : АСTOH, 2002. $212 \mathrm{c}$.

5. Буряк П.Ю., Смолінська С.Д., Татарин П.Б. Фінанси. Київ : «Хай-Тек Прес», 2010. 392 c.

6. Александрова М.М. Гроші. Фінаси. Кредит. Київ : ЦУЛ, 2002. 36 с.

7. Недільська Л.В., Дорохова Л.М., Дем'янюк І.В. Фінансова політика в аграрному секторі економіки: стан та перспектива : монографія. Житомир : ЖНАЕУ, 2015.15 c.

8. Господарський кодекс України : із змінами та допов. на 2 вересня 2011 р. К. : Правова єдність, 2011. 160 с.

9. Терещенко О.О. Фінансова діяльність суб'єктів господарювання. Київ : KHEУ, 2003. 75 c.

10. Павловський С.В. Фінансування підприємств у період фінансової кризи: альтернативні рішення. Науковий вісник Херсонського державного університету. 2016. Вип. 17. С.112-117.

11. Про банки i банківську діяльність : Закон України № 2121-III. URL: https://zakon.rada.gov.ua/laws/show/2121-14 (дата звернення: 07.04.2020). 